\title{
CAUSES OF FISCALITY GENERATING ECONOMIC AND SOCIAL EFFECTS IN ROMANIA
}

\section{Ioan Gabriel POPA}

\author{
"Nicolae Bălcescu” Land Forces Academy, Sibiu, Romania \\ popaigabi@yahoo.com
}

\begin{abstract}
I think I am in the same line with the majority of finance and especially tax specialists in arguing that taxation is an economic and social phenomenon, i.e. a chain of actions and deeds which take place in time and space. The main argument in considering taxation in a broader sense, as an economic and social phenomenon, is that taxation should ensure the achievement of the economic and social objectives of the state. This phenomenon is caused by a complex of factors that are general and perpetual and whose actions breed measurable consequences. Like any economic and social phenomenon, taxation is characterized by generating causes, specific to the time and space framework of the event, vectors of influence of the intensity of the action (accelerators or reducers) and noticeable results (effects) on the surface of the economic reality.

The economic and social causes of the phenomenon of taxation are not usually measurable given the continuous interaction of the vectors of influence, but the effects are real, reliable and quantifiable. Therefore, it is necessary to undertake in-depth studies in order to understand the lesser known side of the elements that trigger the emergence and development of the economic and social phenomena.
\end{abstract}

Keywords: tax, tax evasion, policy, cause, effect.

\section{Introduction}

Like any economic and social phenomenon, taxation is characterized by generating causes, specific to the framework of the event (time and space), vectors of influence of the intensity of action (accelerators or reducers) and noticeable results (effects) on the surface of the economic reality.

Without being limited to research, understanding the concept of cause and effect is essential, as the only way to define the emergence, manifestation and completion of the phenomena and through this approach, to ensure the progress of scientific research. When discussing causes and effects, we generally think of a model able to highlight the interaction between phenomena and the relationship that leads to perceptible and measurable changes.
In an interactive causal process, which taxation is part of, the combined action of a number of factors can cause several effects. They often occur randomly, which eventually requires distinguishing cases in which the same causes determine different effects, depending on the given conditions. Regardless of the angle from which we perceive the evolution of taxation as a phenomenon or as social-economic processes, it does not depend only on hazard. The economic phenomenon is generated and governed by certain rules that are based on one or more causes of initiation and action. The identification, analysis and in-depth knowledge of the causes which generate taxation provide, inter alia: observing its evolution in time, the manifestation in space, the possibility of finding means of diagnosis and effective actions to reduce and mitigate the effects. 
The cause, in the sense used in everyday speech, is, according to the authors Elisabeta Clement and Pierre Kahn "that which produces an effect which is the constant antecedent of a phenomenon".

In this context, we can tackle on the notion of causality, with the meaning the same authors assigned it, as "the principle whereby a given phenomenon is attached to anther that is perceived as being its condition", since we believe that every phenomenon has a cause, that the phenomena are interrelated to each other in a system, and causality is not linear, but rather circular, with a turn of the effect back to the case. In other words, the effects resulting from the action of a cause produce other effects in the context of a wider linkage. In this way, the process can be continuous until the cases are either annihilated or reduced to a reasonable level. This line of thought underlines the early identification of the causes of the action, the initial timing of a process or phenomenon.

\section{Main causes of taxation}

Taxation has positive and negative effects. The positive effects stem from their need and reason, i.e. to ensure the existence of the necessary resources. The negative effects are rooted in an excessive taxation and require finding relevant solutions and measures to mitigate the produced effects. For this reason, the following lines analyze the main causes generating negative effects.

The causes of taxation are:

- Economic policy;

- Social policy;

- Tax evasion;

- Legislative instability.

\subsection{Economic policy}

In a modern society based on a functioning market economy, the state should exercise its increased economic role in all countries, in particular historical conditions and depending on their actual development. Since economically wise, the target of the state should be macroeconomics, the state must come up with mechanisms for influencing the economy. In specialized literature, economic policy is presented as "the conscientious action of public power, democratically established, involving the scientific definition of economic and social objectives of the nation-state for a certain period of time and the implementation of these objectives, starting form the existing conditions (premises) and using the suitable means and techniques "[1], which on the one hand refers to the interventions of the state to correct the imbalances that may occur at the level of the national economy, and, on the other hand, define all the decisions taken by the public power, designed to achieve through the use of instruments, safe aims related to the economic situation.

The economic policy determines the legislator to choose between taxes on income, on capital and on expenditures, or to combine them. The aim is wealth, but it does not always have the same economic nature.

Among its objectives, the economic policy aims at establishing the fiscal system, meaning imposing taxes and compulsory social contributions.

The scope of the economic policy comprises fiscal policy, budgetary and monetary policy. In the following lines we will pursue the research in order to identify their main objectives.

When we discuss fiscal policy, we must take into account both the amount and the sources of origin of the public budget resources. We also need to identify sampling methods to be used according to the objectives of the state and the modalities to accomplish them.

Fiscal policy is based on several criteria, of which the tax efficiency criterion is the one indicating whether or not a new form of sampling is efficient or not. Therefore, the desire of fiscal policy is to ensure a large amount of public revenues while creating proper conditions to encourage business investment, without overlooking maintaining the tax equity as 
related to the ability of the taxpayers to provide public income revenues. Tax policy tasks include:

- designing the general system design of taxes and mandatory social contributions;

- identifying the general and particular level of taxation;

- establishing timely public budget revenues within the amount envisaged by taxes and mandatory social contributions with high tax yield;

evasion.

- preventing and combating tax

Fiscal policy uses the fiscal system with the same purposes as the public authorities. As an instrument of political decisions, the tax system will influence the social, economic and political life of the state. Fiscal policy is primarily based "on the existing financial and economic potential to be 'exploited' in terms of financial and fiscal limits, but with maximum efficiency" [2]. A very well promoted and applied fiscal policy must increase the economic potential of a country so as to fully meet the social needs of the population.

Political power uses fiscal policy as a lever to achieve the economic policy of a state. Thus, fiscal policy is "an indirect form of state intervention in the economy" [3] and is applied to the aggregated market of goods and services, which is why fiscal policy is associated with consumer and saving behavior of the businesses. Consequently, increased taxation and parataxation will reduce the disposable income of businesses, while their aggregated reduction over time has the opposite effect. The fiscal policy of a state also measures the degree to which the state intervenes in the economy. Forms of state intervention in the economy form a whole, interfering and being mutually conditioned.

The results of the economic activity of the state will encourage or discourage taxation depending on the way in which this outcome is materialized, i.e. increasing or decreasing production activities, changing the standard of living, the manner in which social needs are covered, ensuring higher or lower revenues for the state.

When referring to the actions of the state in relation to the budgeting of the income, to the means and methods of constituting them and to their use for specific destinations, that nurture stability and economic development, we must refer to budget policy. Budget policy can be found in the legal document called public budget, which is the main means of presenting the formation of public revenues and the manner of spending them.

In order to achieve a goal or action, the state must identify all real solutions that lead to choosing the best option, i.e. the best ratio between the expected effect and effort in activating, validating, and authorizing expenditures.

In what concerns fiscal policy, taxes and mandatory social security contributions are nothing but genuine sampling channels for the financial resources from the public budget, but they are also tools that can be influenced by economic processes.

According to Professor Bistriceanu, monetary policy "represents all the principles, rules, measures and instruments used by the state through the central bank or monetary authorities to regulate the issue, circulation and withdraw of money from circular arteries to exert proper influence on the national economy, in order to ensure stability of prices and exchange rates and control inflation"'[4]. Monetary policy should be designed in accordance with the budgetary and fiscal policy and represents all the decisions that alter the amount of currency and interest rates in economy and are intended to amend the national income and prices. The objectives of monetary are subsumed to the objectives of the general economic policy, i.e. economic growth, internal and external stability of the currency etc. The implementation of monetary policy is conducted using tools that are designed to influence credit directly and bank liquidity indirectly. Monetary policy should ensure a better 
correlation between the household income and the amount of goods on the market or the growth of labor productivity and the average wage growth.

\subsection{Social policy}

Social policy is made by the political power of the state, i.e. the government, by which it is believed to affect some of the public revenues constituted for the achievement of social objectives proposed by the government plan. From this perspective the political power wants the proposed regulatory framework for achieving its social policy to impose objectives. To achieve objectives such as social protection, education, health and the growth of living needs of the population, the government can use a regulated system of measures, activities or programs that redistribute some of the resources available. Moreover, social policy is reflected in all activities in the economic, cultural, educational, demographic, national minorities, gender, environment fields.

Social policy objectives can be grouped as follows:

- promoting public goods (defense, security, infrastructure, health, education, culture, science);

- social protection of social groups in need;

- social development in general.

In terms of social option, taxation broadly depends on the choice between types of taxes and obligatory social contributions. In order to assess the performance of the financial obligations to the state, these must be analyzed in terms of tax efficiency and fiscal equity.

\subsection{Tax evasion - cause and effect of taxation}

One of the most complex economic and social phenomena with negative effects on society and especially on the tax-paying citizen, a phenomenon that all countries face, is tax evasion. Tax evasion acts directly downwardly on fiscal revenues and eventually leads to market distortions. Most often, it contributes to the emergence or deepening of social inequalities arising from the taxpayer's inclination towards evading taxation, due to excess fiscality, so to tax evasion. It is both the cause and effect of taxation.

Tax evasion is a cause of taxation because it has a negative impact on the efficiency of financial obligations, reducing their efficiency, thus reducing tax revenues and, at the same time, it is an effect of taxation determined by high fiscal pressure or even excessive taxation (fiscality), which leads to the hiding or the non-reporting of taxable assets, that encourages the black market and the finding of other methods and procedures of protection against excess tax.

Tax evasion can be defined as "all legal and illegal methods by which those interested hide, in whole or in part, their taxable material obligations under the law tax" [5]. The same approach on tax evasion is found in Văcărel [6], Tulai [7], Drăgoescu [8] etc. The above definition and the convergent opinions of the authors listed above lead to the assertion that tax evasion is precisely the essence of evading payment of financial obligations imposed on the taxpayer by the legislature.

Another approach to tax evasion or a paraphrase of the previous one is given by C. Corduneanu [9] " ... is the circumvention of the stealing taxpayers from paying tax obligations partially or totally incumbent on them, using loopholes or resorting to ingenious maneuvers, so as to conceal taxable assets". This definition expands the scope of tax evasion to everything that leads to the reduction of taxable assets, whether or not endorsed by the legislature, since tax evasion is not the only form of non-taxation. It is supplemented by tax concessions, exemptions or reductions of taxes and mandatory contributions stipulated by the tax legislation regulations with express provisions in this regard. Although these forms of non-taxation of income inexorably lead to the reduction of public resources, they are not accomplished by the taxpayers' evading the payment of the 
money. Therefore they cannot be included under the definition of tax evasion.

According to the criterion of legality, Romanian specialized literature identifies two terms used to denote the form of tax evasion: lawful tax avoidance (legal) and illegal tax evasion (fraudulent). In the opinion of C.V. Brown [10], the two types of tax evasion are “... a legal reorganization of a business so as to minimize tax liability and tax fraud as an illegal reorganization of a business for the same purpose".

Morally wise, the ways to avoid taxes using legal instruments are as bad and fraudulent as the phenomenon of evasion itself and therefore I believe they should be treated accordingly.

Typical activities of tax evasion determines the contributor to adopt complex decisions under uncertain conditions, that is to be found and ordered to pay financial obligations and accessories.

In other words, even if there is a distinction between the two forms of tax evasion, licit or illicit, I think that can it can only be done theoretically (legal tax evasion does not exist in practice because it involves a non sense). However, this distinction is necessary because it enables the estimation of the phenomenon and raises awareness of the competent authorities to search and establish appropriate means to limit and control the phenomenon.

In practice, the taxpayer's repeated attempts to use the gaps in the law or even fiscal incentives sometimes materialize in violation of the law.

\subsection{Legislative instability}

The frequent changes to tax legislation have created "disorder" in the Romanian taxation, with consequences for the taxpayer's timely fulfillment of tax liabilities in the exact amount. They learned that it is possible to postpone on a long or short term the payment of the financial obligations to the state. This custom was transformed into a real practice of tax evasion.

The legislative process was often out of control, and important laws in the field have been issued by government emergency ordinances or government decision, approving the orders of finance ministers.

Related to legislative instability, one aspect noticed in recent years refers to a wide range of procedural "tricks" to put legal acts on a normal path. In practice, creating a climate of legislative instability, leads to delaying or even deterring investment which ultimately affects the economy and society. This has also affected Romania's position as the EU and as a NATO member. Creating a climate of legislative instability is determined by numerous procedural improvisations starting from the tax code and tax procedure and ending with law emergency ordinances.

As an example, according to art. 4 par. (1) of the Fiscal Code, amendments and additions may be made only by law, normally promoted six months before the date of entry into force. "Normally" has become has become a habit and it often means a loophole to justify legislative instability.

Even if de bona fide, central or local government propose legislation projects in the field of taxation, which most often succeed so quickly that it makes it impossible for taxpayers to keep up with them.

Legislative instability, bureaucracy and corruption are the main factors that investors take into account, and they fear that they may adversely affect the success of investment activities.

Developing precise and clear tax laws, without gaps favoring tax evasion by exploiting its loopholes should be an important focus of government programs.

\section{Conclusions}

The above suggest that the taxing causes refer to facts generating effects or the factors acting on them, causing them to react, that is to take effect. 
The causes of taxation can be grouped according to several criteria which include:

a) according to their nature:

- objective causes, generating main effects of taxation;

- subjective causes, generating and "helping" the taking effect of taxation.

b) according to the manifestation frame:

- internally: legislative instability, legal inconsistency, economic instability, tax evasion, corruption, arrears etc;

- internationally: global financial and economic crisis, international double taxation, non harmonization of tax systems etc.

c) depending on the field of event:

- social: psychological causes such as the behavior of the taxpayer to taxation and para-taxation, tax education, profession, religion and marital status of the taxpayer;

- economic: specifically pertaining to the remaining income, capital or assets after the payment of taxes and compulsory social contributions etc;

- legal: causes related to legal and administrative factors, settlement and collection of financial obligations, equity of the tax system etc.

Without claiming to exhaustively discuss the form of manifestations of the causality of taxation, the focus was to highlight the main causes, admitting the fact that in the economic reality taxation is influenced by other factors that may be considered as arising from the above.

\section{References}

[1] University Professor Dr. Angelescu Coralia et al., Dicţionar de Economie, Economică Publishing House, Bucharest, 2001, pp. 337;

[2] Nicolae Hoanţă, Evaziunea Fiscală, C.H.Beck Publishing House, Bucharest, 2010, pp.311;

[3] Moldovan I., Finanţe publice, Alma Mater Publishing House, Sibiu, 2003, pp.3;

[4] University Professor Dr G.D.Bistriceanu, Mică Enciclopedie de Finanţe, Monedă, Asigurări, Vol.III, Universitară Publishing House, Bucharest, 2006, pp.79;

[5] Dan Drosu Şaguna, Tuturgiu Mihaela, Evaziunea fiscală, Oscar Print Publishing House, Bucharest, 1995,p.p.20;

[6] Iulian Văcărel, et al. Finanţele publice, Didactică şi pedagogică Publishing House, Bucharest, 2002, pp.475;

[7] Constantin I.Tulai, Finanţele publice şi Fiscalitatea, Cartea Cărţii de Ştiinţă Publishing House, Cluj Napoca, 2003, pp.297;

[8] Elena Drăgoescu, Finanţe Publice, Dimitrie Cantemir Publishing House, Tg.Mureş,2006, pp.174;

[9] Carmen Corduneanu, Sistemul fiscal în Ştiinţa Finanţelor, Codecs Publishing House, Bucharest, 1998, p.374;

[10] C.V. Brown, P.M.Jakson, Public Sector Economics, Basil Blackwell Publishing House, Oxford, 1982, pp. 227. 